Favio Akiyoshi Toda

Um Estudo sobre a Inovação nas Escolas Municipais da Cidade do Rio de Janeiro: Fatores Contribuintes e Relação com o Desempenho

Tese de Doutorado

Tese apresentada ao Programa de Pósgraduação em Administração de Empresas da PUC-Rio como requisito parcial para obtenção do título de Doutor em Administração de Empresas.

Orientador: Prof. Jorge Ferreira da Silva Co-orientadora: Profa ${ }^{\text {. Angela Maria }}$ Cavalcanti da Rocha

Rio de Janeiro Setembro de 2013 
Favio Akiyoshi Toda

\section{Um Estudo sobre a Inovação nas Escolas Municipais da Cidade do Rio de Janeiro: Fatores Contribuintes e Relação com o Desempenho}

Tese apresentada como requisito parcial para obtenção do grau de Doutor pelo Programa de Pós-graduação em Administração de Empresas da PUC-Rio. Aprovada pela Comissão Examinadora abaixo assinada.

Prof. Jorge Ferreira da Silva Orientador Departamento de Administração - PUC-Rio

Prof ${ }^{a}$. Angela Maria Cavalcanti da Rocha Co-Orientadora Departamento de Administração - PUC-Rio

Profa. Flávia de Souza Costa Neves Cavazotte Departamento de Administração - PUC-Rio

Prof. Jorge Manoel Teixeira Carneiro Departamento de Administração - PUC-Rio

Prof. Otávio Henrique dos Santos Figueiredo UFRJ

Prof. Renato Dourado Cotta de Mello UFRJ

Profa. Mônica Herz Vice-Decana de Pós-Graduação do CCS Rio de Janeiro, 6 de setembro de 2013 
Todos os direitos reservados. É proibida a reprodução total ou parcial do trabalho sem a autorização da universidade, do autor e dos orientadores.

\section{Favio Akiyoshi Toda}

Graduado em Estatística pela Escola Nacional de Ciências Estatísticas do IBGE (ENCE/ IBGE) em 1993. Mestre em Administração de Empresas pelo Instituto COPPEAD da Universidade Federal do Rio de Janeiro (COPPEAD/ UFRJ) em 2001. Atuou como executivo em empresas das áreas de Comunicação, Bancária, e de Telecomunicações, além de serviços de consultoria em organizações das áreas de Energia, Consultoria, Varejo etc. Leciona em cursos de graduação e pós-graduação desde 2001.

Ficha Catalográfica

Toda, Favio Akiyoshi

Um estudo sobre a inovação nas escolas municipais da cidade do Rio de Janeiro: fatores contribuintes e relação com o desempenho / Favio Akiyoshi Toda ; orientador: Jorge Ferreira da Silva ; coorientadora: Angela Maria Cavalcanti da Rocha.

168 f. ;30 cm

Tese (doutorado)-Pontifícia Universidade Católica do Rio de Janeiro, Departamento de Administração, 2013.

Inclui bibliografia

1. Administração - Teses. 2. Inovação. 3. Liderança. 4. Clima organizacional de suporte à criatividade e inovação. 5. Desempenho organizacional. 6. Educação. I. Silva, Jorge Ferreira da. II. Rocha, Angela Maria Cavalcanti da. III. Pontifícia Universidade Católica do Rio de Janeiro. Departamento de Administração. IV. Título.

CDD: 658 
Para Nossa Senhora,

Mãe, protetora e orientadora. 


\section{Agradecimentos}

Aos queridos orientadores Jorge Ferreira da Silva e Angela da Rocha (uma mãe intelectual para quem tenho uma profunda admiração e orgulho de ser seu eterno aluno).

Para a PUC-Rio, pelo auxílio concedido, sem o qual este trabalho não poderia ter sido realizado.

Aos colegas e amigos da PUC-Rio, do IAG, professores e funcionários, meus alunos do curso de Graduação, colegas do curso do Doutorado, em especial a Maria Angélica Luqueze, e também a Teresa Campos, secretária do Departamento de Pós-Graduação pela sua disposição em sempre ajudar.

Para as professoras do Departamento de Educação, Dra. Fátima Alves e Dra. Helena Corrêa de Vasconcelos, respectivamente da PUC-Rio e UFRRJ pelas contribuições e críticas construtivas para a realização desta tese.

Aos professores e funcionários da Secretaria Municipal de Educação do Rio de Janeiro, principalmente àqueles que mantem dentro de si a preocupação e lutam por um ensino de qualidade. Uma atenção em especial ao Sr. Antonio Augusto pela colaboração importante para a realização deste trabalho.

Para meus pais pelos enormes sacrifícios que fizeram para educar seus filhos. Ao meu irmão e irmã por ajudarem para que eu pudesse me dedicar aos estudos. Ao amigo-irmão Winarto.

Para os amores da minha vida. Minhas filhas Amanda Yumie e Thalyta Mitsue, que tiveram que ter muita compreensão e paciência com um pai estressado, e, por vezes, ausente durante este estágio da minha vida profissional. E para Patrícia Nogueira, minha alma-gêmea. 


\section{Resumo}

Toda, Favio Akiyoshi; Silva, Jorge Ferreira da. Um Estudo sobre a Inovação nas Escolas Municipais da Cidade do Rio de Janeiro: Fatores Contribuintes e Relação com o Desempenho. Rio de Janeiro, 2013. 168p. Tese de Doutorado - Departamento de Administração, Pontifícia Universidade Católica do Rio de Janeiro.

O conhecimento é visto, cada vez mais, como importante condutor do crescimento econômico e da inovação, o que desperta interesse crescente pela melhoria da educação. O Brasil não é exceção: a sociedade brasileira encontra-se cada vez mais consciente da necessidade de aprimorar os mecanismos pelos quais se processa a educação. Por outro lado, do ponto de vista teórico, existe ainda, na literatura, a preocupação em entender de que forma os construtos de liderança e clima organizacional de suporte à criatividade e inovação impactam a inovação nas organizações e, em decorrência, seu desempenho. Este estudo buscou, portanto, atender a uma preocupação social, a melhoria da educação, ao mesmo tempo em que contribui para o entendimento das complexas relações entre fatores internos à organização e seu impacto sobre a inovação conduzida na organização e o desempenho por ela obtido. Assim, as organizações escolhidas para o estudo foram escolas públicas da cidade do Rio de Janeiro. A revisão bibliográfica focou a literatura sobre liderança e papel dos líderes na condução da inovação, já que grande parte das inovações não resulta do acaso, mas sim de efetiva gestão na busca de solução para problemas que se apresentam no mercado ou dentro das próprias organizações, e na literatura sobre o papel do clima organizacional de suporte à criatividade e inovação, além dos estudos que analisam a relação entre inovação e desempenho das organizações. A partir da literatura estudada, foram identificadas escalas desenvolvidas na área de gestão, cobrindo diferentes facetas dos construtos Liderança e Clima Organizacional de Suporte à Criatividade e Inovação. Especificamente, foram usadas as escalas MLQ (Multifactor Leadership Questionnaire - Form 5X) de Bass e Avolio (2004) e o SSSI (Siegel Scale of Support for Innovation) de Siegel e Kaemmerer (1978). O desempenho foi medido por meio de variáveis relativas a aspectos não apenas de aprendizagem de conteúdo por parte dos alunos, mas também motivacionais, relativos à motivação de professores e funcionários e à colaboração de familiares de alunos, 
em preferência a resultados do IDEB (Índice de Desenvolvimento da Educação Básica) do Ministério da Educação e Cultura, composto apenas por questões relacionadas a aprovação e aprendizagem (de português e matemática) dos alunos. A pesquisa de campo junto às escolas municipais do Rio de Janeiro foi realizada entre os meses de fevereiro e abril de 2013, sendo enviados questionários para todas as 358 escolas do município que ofereciam ensino fundamental nos anos finais ( $6^{\circ}$ ao $9^{\circ}$ ano) e que possuíam avaliações do IDEB dos anos de 2007, 2009 e 2011. Os resultados evidenciam os aspectos teóricos do modelo conceitual elaborado, observando-se o efeito da Liderança sobre o Clima Organizacional de Suporte à Criatividade e Inovação, e deste, por sua vez, sobre o Desempenho Inovador da organização. Além disso, conforme esperado, o Desempenho Inovador afeta positivamente o Desempenho Organizacional.

\section{Palavras-chave}

Inovação; liderança; clima organizacional de suporte à criatividade e inovação; desempenho em inovação; desempenho organizacional; educação. 


\section{Abstract}

Toda, Favio Akiyoshi; Silva, Jorge Ferreira da (Advisor). A study on innovation in public schools of the city of Rio de Janeiro: contributing factors and relationship with the performance. Rio de Janeiro, 2013. 168p. Doctoral Thesis - Departamento de Administração, Pontifícia Universidade Católica do Rio de Janeiro.

Knowledge is seen increasingly as an important driver of economic growth and innovation, which arouses increasing interest for the improvement of education. Brazil is no exception: the Brazilian society is increasingly aware of the need to enhance the mechanisms by which education takes place. On the other hand, from a theoretical point of view, still exists in the literature, the concern to understand how the constructs of leadership and organizational climate to support creativity and innovation in organizations impact innovation and, as a result, its performance. This study aimed, therefore, to meet a social concern, improving education, while contributing to the understanding of the complex relationships between factors internal to the organization and its impact on innovation conducted in the organization and performance obtained by it. Thus, the organizations chosen for the study were public schools in the city of Rio de Janeiro. The literature review focused on literature on leadership and the role of leaders in driving innovation, since a large portion of the innovations is not the result of chance, but of effective management in the search for solutions to problems that arise in the market or within their own organizations, and literature on the role of organizational climate to support creativity and innovation, including studies that examine the relationship between innovation and performance of organizations. From the literature studied, developed scales were identified in the management area, covering different facets of the constructs Leadership and Organizational Climate to Support Creativity and Innovation. Specifically, the MLQ scales were used (Multifactor Leadership QuestionnaireForm 5 x) on Bass and Avolio (2004) and the SSSI (Siegel Scale of Support for Innovation) of Siegel and Kaemmerer (1978). Performance was measured by variables related to aspects not only learning content by students, but also motivational, concerning the motivation of teachers and staff and cooperation of family members of students, in preference to the results IDEB (Basic Education 
Development Index) of the Ministry of Education and Culture, composed only for issues related to adoption and learning (of portuguese and mathematics) of the students. The field research in the public schools of Rio de Janeiro was conducted between February and April 2013, being sent questionnaires to all 358 municipal schools offering elementary school in the final year (6th to 9th grade) and who had ratings IDEB the years 2007, 2009 and 2011. The results show the theoretical aspects of the conceptual model drawn, observing the effect of Leadership on Organizational Climate to Support Creativity and Innovation, and this, in turn, on Innovative Performance of the organization. Furthermore, as expected, the Innovative Performance positively affects organizational performance.

\section{Keywords}

Innovation; leadership; organizational climate to support creativity and innovation; performance in innovation; organizational performance; education. 


\section{Sumário}

1. INTRODUÇÃO

1.1. APRESENTAÇÃO DO TEMA

1.2. DEFINIÇÃO DO PROBLEMA E OBJETIVOS

1.3. DELIMITAÇÃO DO ESCOPO DO ESTUDO 19

1.4. RELEVÂNCIA DO ESTUDO 20

1.5. ORGANIZAÇÃO DO ESTUDO 21

2. REFERENCIAL TEÓRICO 23

2.1. INOVAÇÃO 23

2.2. RBV E INOVAÇÃO

2.3. COMPETÊNCIAS DINÂMICAS PARA A INOVAÇÃO 29

2.4. TIPOS DE INOVAÇÃO, ATIVIDADES DE INOVAÇÃO E MODELOS DE INOVAÇÃO

2.4.1. TIPOS DE INOVAÇÃO

2.4.2. ATIVIDADES DE INOVAÇÃO E MODELOS DE INOVAÇÃO

2.5. INOVAÇÃO EM SERVIÇOS

2.6. INOVAÇÃO NA EDUCAÇÃO 43

2.7. MOTIVAÇÃO E APRENDIZAGEM

2.8. DESEMPENHO INOVATIVO

2.9. A MENSURAÇÃO DO DESEMPENHO EM INOVAÇÃO

2.10. MENSURAÇÃO DO DESEMPENHO EM INOVAÇÃO NA EDUCAÇÃO

2.11. DESEMPENHO ORGANIZACIONAL

2.12. MENSURAÇÃO DO DESEMPENHO ORGANIZACIONAL NA

EDUCAÇÃO

2.13. LIDERANÇA

2.14. LIDERANÇA TRANSFORMACIONAL 75

2.15. INSTRUMENTOS PARA MENSURAÇÃO DA LIDERANÇA

2.16. CLIMA ORGANIZACIONAL DE SUPORTE À CRIATIVIDADE E

2.17. INSTRUMENTOS PARA MENSURAR O CLIMA DE SUPORTE À

CRIATIVIDADE E INOVAÇÃO

2.18. TRABALHOS EMPÍRICOS ENCONTRADOS QUE RELACIONAM OS 89 CONSTRUTOS ESTUDADOS

3. METODOLOGIA 94

3.1. MODELO CONCEITUAL E HIPÓTESES DE PESQUISA 94

3.2. OPERACIONALIZAÇÃO DO MODELO CONCEITUAL 97

3.3. MÉTODO DE PESQUISA 102

3.4. POPULAÇÃO E AMOSTRA 103

3.5. INSTRUMENTO DE COLETA DE DADOS 104

3.6. LEVANTAMENTO DE CAMPO 106

3.7. MÉTODO PARA A ANÁLISE DOS DADOS 109

3.8. LIMITAÇÕES DO MÉTODO 110 
4. ANÁLISE DOS RESULTADOS

4.1. CONSIDERAÇÕES SOBRE PROCEDIMENTOS RELATIVOS À AMOSTRA UTILIZADA

4.2. CARACTERIZAÇÃO DA AMOSTRA 114

4.3. MODELAGEM

4.3.1. MODELO DE MEDIDAS DOS CONSTRUTOS - VALIDADE E CONFIABILIDADE

4.3.2.ANÁLISE DOS RESULTADOS

5. CONCLUSÕES E RECOMENDAÇÕES, LIMITAÇÕES E SUGESTÕES PARA FUTUROS TRABALHOS

5.1. SÍNTESE DO ESTUDO

5.2. CONTRIBUIC̃ÕES DO ESTUDO

5.3. LIMITAÇÕES DA PESQUISA

5.4. SUGESTÕES PARA FUTUROS TRABALHOS

6. REFERÊNCIAS BIBLIOGRÁFICAS 


\section{Lista de figuras}

Figura 1 - Tipo de organização e inovação 57

Figura 2 - Evolução do campo da Mensuração do Desempenho 64

Figura 3 - Modelo conceitual proposto 95

Figura 4 - Instrumentos de medidas para avaliação dos construtos 102

Figura 5 - Modelo Estrutural com os coeficientes padronizados $\quad 128$

Figura 6 - Modelo conceitual final $\quad 135$ 


\section{Lista de tabelas}

Tabela 1 - Bases de dados construídas na pesquisa

Tabela 2 - Distribuição das Escolas entre as Coordenadorias Regionais de

Educação (CRE) na População Estudada e na amostra

Tabela 3 - Quantidade de professores registrados porescola na amostra

Tabela 4 - Tempo em que a atual diretora está em exercício no cargo de direção da escola na amostra

Tabela 5 - Instrumentos, escalas e itens para mensuração dos construtos

Tabela 6 - Cargas fatoriais dos indicadores para com o seus respectivos

Construtos e a probabilidade $p$-valor

Tabela 7 - Medidas para Avaliação da Validade Convergente e Confiabilidade

Tabela 8 - Matriz de Validade Discriminante

Tabela 9 - Matriz de Correlação entre os Construtos

Tabela 10 - Índices de ajuste do modelo de medidas

Tabela 11 - Índices de ajuste do modelo estrutural

Tabela 12 - Resultados dos testes de hipóteses

Tabela 13 - Índices de ajuste do modelo estrutural

Tabela 14 - Coeficientes padronizados e significâncias entre modelos concorrentes

Tabela 15 - Índices de ajuste do modelo estrutural na amostra de Diretores que

também estavam ocupando a posição em 2009

Tabela 16 - Coeficiente padronizado e a indicação dos níveis de significância entre as amostras 


\section{Lista de Quadros}

Quadro 1 - Conceituações de Inovação 24

Quadro 2 - Atividades em Inovação segundo a OCDE 36

Quadro 3 - Diferenças entre as Empresas quanto às suas atitudes nos Modelos de Inovação Aberta e Fechada 39

Quadro 4 - Possibilidades de inovações segundo Sawhney, Wolcott, e Arroniz 45

Quadro 5 - Inovações em Escolas Inovadoras $\quad 47$

Quadro 6 - Práticas ou Atividades de Inovação Extraídas de Noticiários 48

Quadro 7 - Princípios Básicos Gerais da Neuroeducação 54

Quadro 8 - Princípios básicos da Neuroeducação que explicam diferenças individuais $\quad 55$

Quadro 9 - Diferenças entre as IGOs e IAOs 58

Quadro 10 - Caracterização da Liderança sob a perspectiva de contexto $\quad 74$

Quadro 11 - Diferenças entre Cultura e Clima Organizacional 82

Quadro 12 - Dimensões da escala CQC da versão original sueca 86

Quadro 13 - Dimensões da escala KEYS

Quadro 14 - Dimensões da escala TCl 88

Quadro 15 - Resumo de estudos empíricos e relações entre os construtos 90 